\title{
Milton, the Gunpowder Plot, and the Mythography of Terror
}

\author{
Robert Appelbaum
}

At magis horrendum sol nunquam viderit aut quod / (Ut veram fatear) propius pervenit ad Actum [The sun has never seen a more horrible act, or at least one that (to tell the truth) came nearer to being an act]. - John Ross, Ad Praesens Tempus Apostrophe

$\mathbf{H}$ ow to suggest the scale of it?" the historian Garry Wills once asked. ${ }^{1}$ Writing about the Gunpowder Plot, he could not come up with any modern parallel to it. So instead he asked his readers to imagine a confrontation during the Cold War between the United States and the old Soviet Union and a secret plot to set off a nuclear bomb in the American Capitol. He was writing before 9/11, obviously. But Wills, concerned primarily with Macbeth, was at least among the first to see that, however one should suggest its scale, the plot was in its own day the subject of a vast literary output, interesting in its own right, with authors like William Shakespeare, Ben Jonson, and Thomas Dekker weighing in, and remarkable as an example of how history, politics, and literature can be intertwined.

In fact, in the seventeenth century the output was even vaster than Wills suggested. There were journalistic accounts, memoirs, sermons, fictionalizations, allegorizations, lyric poems, political and philosophical meditations. The so-called King's Book (1605), which documents proceedings and statements responding to the plot, including the confessions of Guy Fawkes and Thomas Winter and the speech of James VI and I to Parliament, provided what was intended to be an

${ }^{1}$ Garry Wills, Witches and Jesuits: Shakespeare's "Macbeth" (New York: Oxford University Press, 1995), 13 .

Modern Language Quarterly 68:4 (December 2007)

DOI 10.1215/00267929-2007-012 @ 2007 by University of Washington 
official account. ${ }^{2}$ But other official and not-so-official treatments followed quickly, including editions that incorporated material from The King's Book while adding new material of their own. ${ }^{3}$ Edward Hawes, an otherwise unknown writer, came out with Trayterous Percies and Catesbys Prosopopeia (16o6), a "personification" in verse of two of the dead perpetrators, which transforms them into unrepentant Machiavels. Dekker issued a pair of works within the year, The Double P.P. (16o6), a clever exercise in propaganda, rendered in mock-heroic verse, and The Whore of Babylon (16o6), a historical drama about terrorist plots sponsored by the pope against England in the time of Elizabeth; it was clearly meant to say something to its audience about the attempt by Catholics against the king, his family, and Parliament. There were direct, moralizing accounts, too, like William Leigh's Great Britaines Great Deliuerance from the Great Danger of Popish Powder (1606), and more oblique treatments, like Thomas Morton's Exact Discoverie of Romish Doctrine in the Case of Conspiracie and Rebellion (1605), which mentions the plot and perhaps was written because of it but puts no particular emphasis on it. Then there are the fictionalizations - narrative poems, dramas, prose works - which either tell similar or parallel tales about political violence or else embroider the real story with allegory and imaginary incidents. Both Macbeth (first performed in 1606) and Jonson's Catiline (1611) have the plot in mind, though they deal with it only indirectly, but there are many other plays at whose core lies an allusion to a plot to destroy a nation by sabotage and assassination in the name of religion: The Tempest, for example, where Caliban's choice of conspiracy

${ }^{2}$ His Maiesties Speach in This Last Session of Parliament as Neere His Very Words as Could Be Gathered at the Instant. Together with a Discourse of the Maner of the Discouery of This Late Intended Treason, Ioyned with the Examination of Some of the Prisoners (London, ${ }_{1605}$ ). Unless otherwise indicated, the place of publication for works mentioned in this essay is London. Throughout I have kept to the original dates of publication as noted on the title pages, without attempting to adapt dates to the new style. Some 1605 publications may well have appeared during the new-style 1606.

3 The most commonly cited edition of The King's Book is actually a Restoration compilation, with a new and very interesting preface: J. H. Gent, ed., A True and Perfect Relation of That Most Horrid and Hellish Conspiracy of the Gunpowder Treason Discovered the $5^{\text {th }}$ of November, Anno Dom. I605 (London, 1662). This edition should probably be regarded as a new contribution to the literature of the plot, rather than a mere replication of earlier material. 
and assassination is also a choice of a new god. ${ }^{4}$ Poems beginning with Francis Herring's Pietas Pontificia (16o6), first translated as Popish Pietie (1610) and then enlarged by John Vicars into Mischeefes Mysterie (1617), and including Thomas Campion's De Puluerea Coniuratione (1615?) and John Milton's In Quintum Novembris (1626), dramatize and allegorize the plot, working in the vein of a kind of creative nonfiction; they depict it as a satanic conspiracy, which reaches first into the papacy and then to Robert Catesby and his fellow conspirators. No less a work than Paradise Lost (1667) alludes to the plot; it has roots in another poem directly about the plot, Phineas Fletcher's Locustae (1627), and reiterates motifs that first appear in In Quintum Novembris. ${ }^{5}$ Finally, there are works like Thomas Otway's Venice Preserved (1682). Among the most popular stage plays of the 1680s, Otway's tragedy concerns a Gunpowder-like plot and must be included in any bibliography of the literature of the plot, but its main source was a conspiracy in Venice in 1618, and its immediate frame of reference was the Popish Plot of 1678 . In fact, once the Gunpowder Plot was a part of the folklore and literature of England, it became a point of reference for all manner of texts responding to other plots, suspected plots, and outbreaks of political violence. In 1642, for example, in defense of an uprising of London apprentices, a pamphleteer put forward an effort called A Terrible Plot against London and Westminster Discovered, Showing How Colonel Lunsford the Papist . . . Should in a Conspiracy among the Jesuits and Other Papists Have Blown Up the City of London. Surely, there had never been any such plot. Popular opposition to Sir Thomas Lunsford and his appointment as officer of the arsenal of London was a prelude to the armed opposition of the Parliamentary Party to the Royalists: Lunsford was neither a Papist nor

4 On Jonson see B. N. De Luna, Jonson's Romish Plot: A Study of "Catiline" and Its Historical Context (Oxford: Clarendon, 1967). On Shakespeare and Macbeth I have written an article, not yet published, "Theatre in a Time of Terror." See also Wills; and Richard Wilson, "The Pilot's Thumb: Macbeth and the Martyrs," in Secret Shakespeare: Studies in Theatre, Religion, and Resistance (Manchester: Manchester University Press, 2004), 186-205.

${ }^{5}$ For the Campion poem, which was never published in print form, see Thomas Campion, De Puluerea Coniuratione (On the Gunpowder Plot), ed. David Lindley, trans. Robin Sowerby (Leeds: Leeds Studies in English, 1987). On Fletcher and Milton see David Quint, Epic and Empire: Politics and Generic Form from Virgil to Milton (Princeton, NJ: Princeton University Press, 1993), 270-81. 
a saboteur, only a king's man in a position where a parliamentary man was wanted. But the legend of the Gunpowder Plot was available to all comers, and so a defense of Parliament's supporters in London could readily be translated into the exposé of a man whom the anonymous author does not hesitate to call "a second Faux or executioner" of "popish designs." 6

Richard F. Hardin, whose discussion roughly corresponds to an earlier one by David Cressy, proposes that the literature demonstrates a "myth in the making," the myth that culminated in Guy Fawkes Day. But that seems too one-sided a view. More than one myth issued from the legend. That England was providentially delivered from a nearly fatal blow, that its deliverance was proof of the greater destiny God had in store for it, and that in marking that proof England had ready to hand a scapegoat in the figure of Fawkes, whose yearly ritual chastisement became the occasion for a religiously sanctioned celebration of national community — such a myth as Hardin discusses clearly developed and developed early. But the literature of the plot often reached more deeply into the politics, the psychology, and the theology of the event, and Fawkes in fact was not often regarded as a central figure in the drama - not when such interesting and troubling men as Catesby and the Jesuit Henry Garnet were part of it. Moreover, not all of the literature was purely Protestant, or purely propagandistic. The Jesuits Oswald Tesimond and John Gerard left behind memoirs on the matter, and ministers ranging from the Puritan separatist Thomas Hooker to the High Church bishop Ralph Brownrig published sermons about it, the one turning the story into a call for righteousness, the other into a call for obedience. ${ }^{8}$ When writers like Shakespeare and Jonson

${ }^{6}$ On Lunsford see the entry in the Oxford Dictionary of National Biography.

${ }^{7}$ Richard F. Hardin, "The Early Poetry of the Gunpowder Plot: Myth in the Making," English Literary Renaissance 22 (1992): 62-79; David Cressy, Bonfires and Bells: National Memory and the Protestant Calendar in Elizabethan and Stuart England (London: Weidenfeld and Nicolson, 1989), chap. 9.

8 The Gunpowder Plot: The Narrative of Oswald Tesimond Alias Greenway, ed. and trans. Francis Edwards (London: Folio Society, 1973); John Gerard, The Autobiography of an Elizabethan, trans. Philip Caraman (London: Longmans, Green, 1951); Thomas Hooker, "The Church's Deliverances," in Four Learned and Godly Treatises (London, 1638), 95-176; Ralph Brownrig, A Sermon on the 5 th of November, Being the Last Which Was Preached by the Reverend Father in God, Bishop Brownrigg [sic]. Bishop of Exon, Thomason Tracts (London, 1659). 
turned their hands to it, they characteristically worked both sides of the story, pursuing a theatricality that was at once moving, troubling, and ambiguous.

It is perhaps more to the point to refer to what Joseba Zulaika and William A. Douglass, in another context, call a "mythography" - a network of discourses and narrative strategies on the theme. ${ }^{9}$ For surely such a many-sided mythography was let loose into English-language letters as soon as the plot was disclosed, a mythography that at times crystallized into distinctive genres and subgenres of creative writing, at times migrated into different media and into literature ostensibly about another subject, and at times deteriorated, as in A Terrible Plot against London, into desperate finger-pointing and hysterical analogizing.

In appealing to the work of Zulaika and Douglass, however, I am alluding to another aspect of the literature of the plot. For we are now more disposed and better prepared to focus on the plot as an episode in the history of terrorism. And so we have new kinds of questions to ask of the plot and the literature it spawned, questions similar to those first raised by Wills but with a new context, a new sharpness of outlook, and a new urgency.

The Gunpowder conspiracy was a terrorist plot. That much is clear. The word terrorism would not appear in European languages until after the French Revolutionary "Terror," it is true, and no one in the seventeenth century knew what to call the incident. "I sing Impiety beyond a name," wrote Milton's contemporary, Richard Crashaw, echoing a common sentiment. "Who stiles it any thinge, knowes not the same."10 "What then could we have called that act, by which they should have been all murdered and mangled at one clasp," wrote George Hakewill in 1626. "Surely, as we want an example to parallel to it, so do we a name to express it."11 But whatever it could or could not be called in the seventeenth century, the plot had all the hallmarks of terrorism as we

${ }^{9}$ Joseba Zulaika and William A. Douglass, Terror and Taboo: The Follies, Fables, and Faces of Terrorism (New York: Routledge, 1996).

${ }^{10}$ Richard Crashaw, "On the Gunpowder Treason," in Steps to the Temple, Delights of the Muses, and Other Poems, ed. A. R. Waller (Cambridge: Cambridge University Press, 1904), $35^{\circ}$.

11 George Hakewill, A Comparison betweene the Dayes of Purim and That of the Powder Treason for the Better Continuance of the Memory of It, and the Stirring Up of Mens Affections to a More Zealous Observation Thereof (Oxford, 1626). 
have come to understand it since the word first was used in its current sense in the nineteenth century. ${ }^{12}$ The plotters endeavored to alter the political condition of the English nation by way of an act of violence, indeed by planting and detonating a weapon of mass destruction. Their targets were noncombatants. In assaulting the Parliament building and its occupants, the plotters were trying to send a message to the world at large, exacting symbolic justice for their cause, and believed that the mass murder they planned would intimidate their enemies, rouse their allies, and eventually incite a revolution. ${ }^{13}$ Their aim was to effect "the deletion of our whole name and Nation," as the jurist Edward Coke would put it, or "the utter ruine of this whole kingdome," as an official proclamation announced. ${ }^{14}$ If this was both impracticable and ruthless, at once idealistic, optimistic, vengeful, heartless, and nihilistic, it was, without qualification, what today we call terrorism. Thus when we look at the literature spawned by the Gunpowder Plot, we may now be disposed to find out how the literary world of the seventeenth century responded to terrorism and the terror it provoked. How did it approach the moral problem posed by the existence of terrorism? How did it manage, or not manage, to put terror into words, and terrorism in its place?

${ }^{12}$ I discuss the problematics of the term and concept of terrorism in the early modern period in the companion article, "Theatre in a Time of Terror." For recent treatments of the definition of terrorism see Martha Crenshaw and John Pimlott, eds., Encyclopedia of World Terrorism, 3 vols. (Armonk, NY: Sharpe, 1997), 1:12-22; Zulaika and Douglass, chap. 4; and Alex Houen, Terrorism and Modern Literature from Joseph Conrad to Ciaran Carson (Oxford: Oxford University Press, 2002), chap. 1. See also the appendix, "Toward a Definition; or, Humpty Dumpty and the Problem of Terrorism," in Walter Laqueur, No End to War: Terrorism in the Twenty-first Century (New York: Continuum, 2003), 232-38.

13 On the plot itself see Joel Hurtsfield, "A Retrospect: Gunpowder Plot and the Politics of Dissent," in Freedom, Corruption, and Government in Elizabethan England (London: Cape, 1973), 327-51; Jenny Wormald, "Gunpowder, Treason, and Scots," Journal of British Studies 24 (1985): 141-68; Mark Nicholls, Investigating Gunpowder Plot (Manchester: Manchester University Press, 1991); Alan Haynes, The Gunpowder Plot: Faith in Rebellion (Stroud: Sutton, 1994); and Antonia Fraser, Faith and Treason: The Story of the Gunpowder Plot (New York: Doubleday, 1996).

${ }^{14}$ Edward Coke, quoted in A True and Perfect Relation of the Whole Proceedings against the Last Most Barbarous Traitors, Garnet a Jesuit, and His Confederates (London, 16o6), D 3 v. For the Proclamation see England and Wales, An Act for a Publique Thanksgiving to the Almightie God, Every Yeere on the Fifth Day of November (London, 16o6), A3. 
A whole treatment of this mythography remains to be written. But it is apposite to discuss, in the context of that mythography, the two works by Milton that have been mentioned: In Quintum Novembris and Paradise Lost. Neither is typical of the literature, and Paradise Lost is only in part about terror, but both are firmly set in the mythography and appropriate much that is typical about it. Given the author's gifts and convictions, they have something to tell us about both the mythography and the terrorism to which it responded. Looking at the works in this light may illuminate larger issues as well. In Quintum Novembris shows the young Milton directly engaged in imagining terrorism, putting it into words, dramatizing it, and trying to draw a moral and political frame around it. Paradise Lost shows Milton endeavoring to explain the existence of evil and, in doing so, drawing on what he has imagined about terrorism.

Curiously, there have been few treatments of the subject of Milton and Gunpowder or Milton and terror. The poet's work on the theme of the Gunpowder Plot has generally been read as an aspect of a larger vision, which comes to fruition only in Paradise Lost, about the nature of the Fall. ${ }^{15}$ Yet on the subject of terroristic elements in Paradise Lost itself, where those earlier ruminations supposedly came to fruition, the critical tradition is mainly silent. A debate has raged about terrorism in another of Milton's works, Samson Agonistes, it is true, but the debate has overlooked the one act of terrorism that Milton had on his mind throughout his career, the Powder Treason, and instead has focused on a context-Milton's experience of defeat in the aftermath of the English Revolution - that had nothing to do with terrorism at all. ${ }^{16}$ The debate on Samson has at times risen to the level of high moral seriousness, even if, due to latent and not-so-latent ambiguities in the text, it has been inconclusive. For Joseph Anthony Wittreich, in fact, the difficulties of making clear judgments about the violence in Samson

15 The tradition takes a beginning for modern criticism with Macon Cheek, "Milton's In Quintum Novembris: An Epic Foreshadowing," Studies in Philology 54 (1957): $172-84$.

16 The other main treatment of the plot in Milton's work appears in Eikonoklastes (1649), which three times openly mentions it and often uses associative terms - plot, treason, conspire - to put readers in mind of it when thinking about Charles I. 
indicate precisely "why Milton matters." 17 But one way or the other, the discussion of Samson has seldom asked what terrorism is or was during Milton's lifetime, or what writing about terrorism is or was. No connections between Samson and the Gunpowder Plot, and the many literary responses to it, have ever been broached, to my knowledge. Nor has anyone in print considered that writing about terrorism and terrorism itself may well constitute not two categorically separate phenomena-a thing and a representation of a thing - but two parts of a general system, a system of geopolitical relations and, even more critically, a system of meaning.

Terrorism speaks. That is what it is intended to do. That it speaks by violence or the threat of violence is a distinction never to be overlooked, but that it is part of rather than apart from the system of meaning it attacks is not to be overlooked, either. The most successful theoretical accounts in the immediate aftermath of that Gunpowder-like plot we call 9/11 — from Jean Baudrillard, Jacques Derrida, and Slavoj Žižek — seem to agree that 9/11 wrought a shock not only to lives but also to a system of meaning: our system, our meaning. ${ }^{18}$ At once internal and external, acting as a "virus," according to Baudrillard, or by means of a "suicidal autoimmunity," according to Derrida, and acting as a realization of the fantasies not only of the perpetrators but also of the victims, according to both Baudrillard and Žižek, the terrorist holocaust attacks the system by way of the system. It says what the system allows and invites and even trains it to say. And that is one of the most shocking things about it.

Parallels between 9/11 and the Gunpowder Plot should not be pressed too far. Above all, the Gunpowder Plot failed. The English

${ }^{17}$ See Joseph Anthony Wittreich, "Why Milton Matters," Milton Studies 44 (2005): 22-39; and Wittreich, Shifting Contexts: Reinterpreting "Samson Agonistes" (Pittsburgh, PA: Duquesne University Press, 2002). The recent debate on Samson was initiated by John Carey, "A Work in Praise of Terrorism? September 11 and Samson Agonistes," Times Literary Supplement, September 6, 2002, 15-16.

${ }^{18}$ Jean Baudrillard, The Spirit of Terrorism, and Other Essays, trans. Chris Turner (London: Verso, 2003); Giovanna Borradori, Philosophy in a Time of Terror: Dialogues with Jürgen Habermas and Jacques Derrida (Chicago: University of Chicago Press, 2003); Slavoj Žižek, Welcome to the Desert of the Real! Five Essays on II September and Related Dates (London: Verso, 2002). See also the discussion "Theory in the Time of Death" in David Simpson, 9/II: The Culture of Commemoration (Chicago: University of Chicago Press, 2006), 121-70. 
responded to the intentions of the conspirators rather than the outcome of their actions. Much of the literature responding to the plot took upon itself the task of imagining those intentions; identifying the motives, persons, goals, and behavior of the conspirators; and representing the holocaust that might have been instead of the pitiful bungling that was: Fawkes caught red-handed in the middle of the night, other conspirators gunned down or swiftly captured and punished. Unlike 9/11, the Gunpowder Plot was never an occasion for mourning, except perhaps among some Catholic partisans and friends of the conspirators. But when writers like Milton put their hand to the Gunpowder Plot, they also had to grapple with the systematicity of the evil.

And how to do that? The young Milton sided unequivocally with the intended victims of the plot. He acknowledged the systematicity of the terror. He saw quite well, as others before him, that the terrorists had colluded to achieve what the system of the English state and church could allow and invite the terrorists to achieve, in terms of both the political violence and the meanings it potentially signified. (Even James VI and I himself, from the outset, saw that the conspirators were, among other things, toying with the apocalyptic fantasies of modern Christianity, including those of Scottish and English churches; Milton himself develops the idea in his short poem "In Proditionem Bombardicam.")19 But Milton was not about to exonerate the conspirators for that reason or, like Baudrillard and Žižek, to critique the system to which both the conspirators and their intended victims belonged. Nor was he inclined to mark the vulnerabilities of the state and its fantasies of self-annihilation, to examine the problem of political violence in a world of religious conflict, or to single out the event as an anomaly, an accident of time, the product of a roguish mentality alien to the real beliefs and hopes of the political and religious world whose interests the conspirators claimed to represent. To tell the story of the plot was rather to justify the state, disown the fantasy, and both generalize and demonize the enemy. It

19 On James see n. 39 below. Milton's short poems on the plot appear as "Elegiarum" in preface to the narrative In Quintum Novembris. "No doubt you thought to send [the king and the English nobility] to high heaven, in a sulphur chariot, with wheels of twisting fame," says the poem in address to "traitor Fawkes" (The Riverside Milton, ed. Roy Flannagan [Boston: Houghton Mifflin, 1998], 202). 
was to abject ideologically the very bond between target and victim that coupled them in the same system of meaning.

So Milton dealt with the problem of representing the plot by way of what might be called a symptomology. As represented by the Gunpowder Plot, terrorism for the young Milton was a symptom of the other. It was not just itself - a policy, a mode of conduct, a strategy, an occupation, an episode of violence, or a way of life. Terrorism was itself only insofar as it expressed a fundamental but asymmetrical opposition. Terrorism was directed, targeted; terrorism was a response, aimed at another for an other and because of an other, indeed because of the legitimacy of the target in opposition to the illegitimacy of what the violence tried to signify. Terrorism thus expressed not only what was wrong and pathological about its perpetrators but also what was sane and right about its intended victims.

As for the late poem, the epic, though Milton was no longer writing as an ideologue, he was still at work on the problem of legitimacy - now calling it the problem of "justification" — and he was still thinking about evil in terms of terrorist aggression. A terrorist mind-set is part of Satan's arsenal of apostasy. Terrorism symptomatizes Satan's traditional role as the Adversary (his original designation in Hebrew); it exemplifies his role as the personification of opposition to the legitimate order, to God and the good and to God's chosen creatures. But terrorism has also been internalized in Paradise Lost. It is not just viral, or infectious; it is constitutive of human existence, which has become part of the system of good and evil. Motifs of terrorism are presented in the epic in fragments. But even so, the prospect of terrorism in the epic is terrible and terrorizing - and part of the framework of universal history.

\section{The Texts}

The Gunpowder poems were written in Latin in 1626, when Milton was only seventeen years of age, then inserted among the Sylvarum Liberinto the Poemata section of his 1645 Poems. They were clearly put forward as juvenilia. But their patriotic fervor and anti-Catholic rhetoric were no more repudiated by the mature author in 1645 than the voluptuary sentiments of his early elegies. 
The poems take the form of a series of epigrams followed by a heroic poem of 226 lines. The form of this heroic poem, In Quintum Novembris, has been explained (by Dana F. Sutton) as an "Alexandrian epyllion": a kind of little epic that "delights in verbal scene-painting" and tends to focus on brief dramatic scenes rather than to develop a narrative fully. ${ }^{20}$ Though the use of the term epyllion in English dates from the nineteenth century, the genre is easily recognized from the extant Roman examples beginning with Catullus, the Virgilian appendix, and Ovid, and among the Latin and vernacular imitations are two poems that Milton almost certainly had read and used as models for In Quintum Novembris: Herring's Pietas Pontificia and Campion's De Puluerea Coniuratione. In fact, this mini-epic style was especially serviceable for sixteenth-and seventeenth-century poets who were working on recent history, concerned with post-Reformation political and religious struggle. By $15^{8} 5$, spurred perhaps by book 4 of Torquato Tasso's Gerusalemme liberata $\left(15^{81}\right)$, the genre in Britain had even adopted a characteristic story: a story of violence plotted, expressed, and thwarted, with victory redounding to the side of true religion, which begins with a conspiracy against the cause of true religion instigated by Satan. A poem of this sort, the anonymous Pareus, probably by George Peele, found its way into print at Oxford in $15^{8} 5$; it tells the story of a thwarted assassination attempt against Queen Elizabeth. By the same year even James VI of Scotland had thrown his weight behind the genre, writing an epyllion on the Battle of Lepanto in which a plot against Christendom is frustrated by a resounding victory at sea. ${ }^{21}$

There seems to have been something of a tradition of teenagers writing poems about the Gunpowder Plot; witness the efforts of Hawes, author of Trayterous Percies and Catesbys Prosopopeia at the age of sixteen, and the apparently early work of Crashaw. And so the young Milton too chose a literary device for reflecting on recent history. Milton minimizes the agency of the perpetrators, however, and all but squeezes

${ }^{20}$ Dana F. Sutton, introduction to John Milton's "In Quintum Novembris" (I626): A Hypertext Critical Edition, par. 2, www.philological.bham.ac.uk/milton/intro.html.

${ }^{21}$ See Robert Appelbaum, "War and Peace in The Lepanto of James VI and I," Modern Philology 97 (2000): 333-65. 
his narrative into a panegyric - akin in spirit to many Gunpowder sermons, as well as to such poems as Acclamatio Patriae; or, The Powder Treason (16o6?), by Richard Williams. ${ }^{22}$ He does not so much recount the plot as explain what caused it and praise the powers that frustrated it. Milton's poem opens with Satan flying over "Albion" and deciding that the country needs to be harmed. There follows a scene in Rome, where he exhorts a corrupt and fleshly pope in a dream to "shatter" the "swollen spirits" of the British and exact vengeance on them for the loss of the Spanish Armada and other injuries. Later the pope sets the plot in motion. Then the poem abruptly flashes forward to an episode in which Fama (Rumor) raises the alarm in time for disaster to be prevented, and it ends with praise at once of God, Fama, and the king whom both have saved. The poem says nothing about Catesby or Fawkes - though Fawkes is addressed in one of the prefatory epigrams - and it follows neither the unraveling of the plot nor the sensational story of its discovery, nor even the equally sensational story of the inquisition, trial, and execution of the terrorists or Garnet, who was implicated with them.

The young Milton would seem to have surrendered his narrative to lyrical and panegyric impulses. He aims directly at the most spectacular of poetic effects, scaling at one point the heights of the heavens, descending at another to the depths of the underworld, all the while pushing his language toward colorful imagery, learned allusion, and verbal virtuosity. To be sure, the poem is uneven and can leave the impression that much of the story has been omitted in haste. ${ }^{23}$ Yet the result is ideologically effective: this poem concisely performs a function that some of Milton's predecessors take a long time to get to - the praise of God, fame, a recently deceased king, and the English state - and does not allow itself to be distracted by mere content. With no ambiguity, with no ambivalence, with no momentary side glances at

${ }^{22}$ Richard Williams, Acclamatio Patriae; or, The Powder Treason, in Ballads from Manuscripts, ed. F. J. Furnivall and W. R. Morfill, 2 vols. (Hertford: Printed for the Ballad Society, 1873), 2:39-59.

${ }^{23}$ Macon Cheek discusses these issues at length, paying particular attention to the Virgilian component of the poem. Cheek overlooks the tradition of Gunpowder poems that Milton drew on, but he does admit that Milton's mini-epic "serves chiefly as a piece of religious propaganda" $\left(1_{3}-84\right)$. 
the passions and grievances of the offenders, or at the personal qualities of their targets, it reproduces terrorism in order to delegitimize it.

Paradise Lost obviously places us in another frame of poetic invention. Perhaps Gordon Teskey is right to characterize it as a work of poetic "delirium," unable to settle into the more stable "hallucination" of allegory, such as In Quintum Novembris might be said to be, or of straightforward narrative, and unwilling to relinquish the pluralities of creativity. ${ }^{24}$ But one cannot deny its affinity with In Quintum Novembris and the similar, more extensive efforts by Fletcher, Locustae and, in its amplified English version, The Locusts; or, The Apollonyists (1627). Once again, Satan is determined to exact some desperate revenge against God and the goodness of the world from which he has been excluded. And once again, knowing that he cannot really defeat God and his Creation, he resorts to what In Quintum Novembris calls "skillful fraud." In the early poem, addressing the pope in the dream, Satan says, "Nec tamen hunc bellis et aperto Marte lacesses. / Irritus ille labor; tu callidus utere fraude" (Do not attack [the English] with war and open conflict; that would be fruitless labor; rather make use of skillful fraud). And he adds:

Right it is to set any sort of snares to catch heretics. Their [the English people's] great king is now summoning to council the dignitaries from the kingdom's remotest shores, the hereditary peers, and the venerable sages with their white hair and robes of state; these limb from limb you can blow to the sky, and blast to ashes. . . Then, when the nation is seized with panic and stunned by the catastrophe, either the ruthless Gaul or the fell Iberian shall invade the land. Thus at length . . . you will rule again over the valiant English. ${ }^{25}$

In Paradise Lost, in a similar situation, Beelzebub as Satan's spokesman urges that the fallen angels shall not need

With dangerous expedition to invade

Heav'n, whose high walls fear no assault or Siege,

${ }^{24}$ Gordon Teskey, Delirious Milton: The Fate of the Poet in Modernity (Cambridge, MA: Harvard University Press, 2006).

25 All quotations of In Quintum Novembris, both Latin and English, are taken from John Milton, ed. Stephen Orgel and Jonathan Goldberg (Oxford: Oxford University Press, 1991), 124-33. 
Or ambush from the Deep. What if we find

Some easier enterprize? $(2.342-45)^{26}$

He inclines toward "some advantageous act" against the new world of the "new race called Man":

either with Hell fire

To waste his whole Creation, or possess

All as our own, and drive as we were driven,

The punie habitants, or if not drive,

Seduce them to our Party, that their God

May prove their foe, and with repenting hand

Abolish his own works. (2.364-70)

In both cases, a guileful aggression is waged against an unbeatable foe; a minor triumph is aimed for, since a total triumph is impossible; and though ruinous devastation of the enemy is anticipated, a moral and political victory is the real goal. The malefactor cannot win; therefore the malefactor lashes out. The impulse toward destruction cannot be satisfied; therefore destruction is planned. Yet destruction-imagined, planned, plotted, or even executed - is only a tactical and emotional stage on the way to a symbolic victory, where what is to be subverted is not the power of the enemy but, however vainly, its authority in all things.

\section{The Situations}

The idea circulating at least since Stella P. Revard's Milton and the Tangles of Neaera's Hair is that the young Milton produced the Gunpowder poems in keeping with the mood of the nation at the time of the death of James VI and I, when many feared that his son Charles I would be too tolerant of Catholicism. ${ }^{27}$ Revard provides little proof, however; in

26 All quotations of Paradise Lost are taken from The Riverside Milton.

27 Stella P. Revard, Milton and the Tangles of Neaera's Hair: The Making of the I645 "Poems" (Columbia: University of Missouri Press, 1997), 86. See also Revard, "Milton's Gunpowder Poems and Satan's Conspiracy," in Milton Studies, vol. 4, ed. James D. Simmonds (Pittsburgh, PA: University of Pittsburgh Press, 1972), 63-78, in which she discusses the sermon tradition, and the revised version in The War in Heaven: "Paradise Lost" and the Tradition of Satan's Rebellion (Ithaca, NY: Cornell University Press, 1980), chap. 3 . 
fact, Charles's England was at war with Spain in 1626 and grimacing at the loss of Bavaria to Catholic forces. No doubt, Milton's In Quintum Novembris is patriotic, but at the time of writing it was not also, then, oppositional.

Since ${ }_{1606}$ the Gunpowder Plot had become officially vested as a day of thanksgiving, and in the end In Quintum Novembris is a poem of thanksgiving (see also Act for a Publique Thanksgiving). It was God, the poem states, who "was moved to pity" the people of England "and thwarted the daring cruelty of the Papists." Thus "honors and sacred incense are offered in gratitude to God; all the joyous crossways smoke with genial fires; the youths in tumult dance, for no day occurs in all the year more celebrated than the Fifth of November." The poem is both a celebration of the event and a celebration of the celebration. And it may well be that to understand this poem, as Hardin conjectures, one needs to understand the anthropology and history of thanksgiving. The transformation of the discovery of the plot into a thanksgiving ritual, regularly denoted in the pulpit and gradually emerging into a day of festivity and a night of bells, bonfires, and scapegoat theatrics, performed a work of ideology. ${ }^{28}$ It would be hasty to reduce the ritual to ideology; there is no reason to suppose that the authors of the ritual, people like James and Lancelot Andrewes (and Andrewes was also scheduled to be in attendance at Parliament on the Fifth of November), did not feel grateful to their god for the turn of events - God having saved them, as Andrewes puts it, quoting Psalm 118, "that we might 'not die but live, and declare the praise of the Lord.'" 29 But the ritual no doubt cemented the feeling to the priorities of national culture, which required both patriotism and a certain brand of worship. That this unusual event was also a nonevent perhaps rendered the public ritual all the more useful to the state. Rather than commemorate a national catastrophe, the ritual was a reminder of a catastrophic intention, with an insistence, on the one hand, that divine power and not human agency had frustrated the desire of the conspirators, and a caution, on the other, that even if the plot had failed and the plotters had been executed, the intention might still be alive, entertained by other

28 See Cressy for the fullest treatment of this topic.

${ }^{29}$ Lancelot Andrewes, Works, 11 vols. (Oxford: Parker, 1841-72), 4:204. 
parties. The obvious lesson was that the English needed to stay the course. The ritual was a call to holy nationhood, understood on the model of the Old Testament and invoked on behalf of a resistance to an apprehension about the future. Hakewill summed it up in the title of a short treatise published at about the same time as Milton was writing on the subject: A Comparison betweene the Dayes of Purim and That of the Powder Treason for the Better Continuance of the Memory of It, and the Stirring Up of Mens Affections to a More Zealous Observation Thereof. Purim was a model for Bonfire Night from the start, a carnivalesque celebration of a national victory over a would-be oppressor. In an impressively judicious and restrained yet morally compelling manner, Hakewill argues that we need to keep remembering the Fifth of November as a marker of the kind of world we live in.

The situation in 1626, insofar as it may be determined, was ritualistic, pious, patriotic, anti-Catholic, literary, and opportunistic. Paradise Lost, by contrast, was not written for or about a ritual occasion. Nor is it concerned with a subject that is obviously material for an epic; on the contrary, as David Quint argues, placing the convention of epic narrative in a story of the Fall and attributing to Satan and the fallen angels most of the military action of the poem verge on a travesty of the epic tradition. ${ }^{30}$ Unlike its ancient models and the early Gunpowder poems, Paradise Lost has nothing in it that smacks of patriotism. If patriotic zeal remained a large part of Milton's work through the interregnum, as late as The Readie and Easie Way (166o), the action of Paradise Lost takes place in a context of history embracing all of humanity, where patriotism is irrelevant. ("All nations" are involved in redemption through Christ, the Archangel Michael stresses to Adam [12:439-46].) Yet if Paradise Lost is not about patriotism, it is still about piety and virtue. And if, unlike In Quintum Novembris, it no longer easily sits in the martial tradition of epic poetry, it still locates itself in it and takes its form; it is still a story about the history of losers and winners and their divine destinies - a task "not less but more heroic," the poet writes, preparing to narrate the Fall (9:14).

But however complex the situation of the poet and the poem when it was written, it is curious that Milton was still thinking about the Gun-

${ }^{30}$ In addition to Quint on this subject, see Neil Forsyth, The Satanic Epic (Princeton, NJ: Princeton University Press, 2003), $56-60$. 
powder Plot and using its mythography as a model for understanding the nature of evil. On the one hand, the epic belongs to the universe of the discourse of the Gunpowder Plot and adopts some of the same basic ontologies; on the other, the epic departs from that discourse considerably. It is not only about a different sort of contest between good and evil; it is also about a different kind of outcome.

\section{The Mythography of Terror and the Symptom of the Other}

Impartiality would not seem to be an option for writers responding to the Gunpowder Plot. ${ }^{31}$ But there are degrees of partiality. The initial pronouncement of James VI and I was judicious. A handful of fanatics, deluded by religious error, were responsible for the plot, but lawabiding Catholics were innocent and not to be condemned. An early sermon commissioned by James, William Barlow's Sermon Preached at Paules Crosse, took a harder line, emphasizing the enormity of the intended crime and the guilt of those who would have perpetrated it. "A cruell execution," he said the plot was, "an inhumane crueltie, a brutish immanitie, a divelish brutishnes, \& an Hyperbolicall, yea an hyperdiabolicall divelishness." 32 With calculated vagueness, harboring metaphor and description in the same accusation, another early writer, the minister John Rhodes, wrote that the "Prince of darkness, and hels blacknes, was [the] leader" of the conspirators, and he did not mean it only figuratively. ${ }^{33}$ In fact, not just the degree of condemnation of the intended violence was in question, but the whole matter of how to frame the plot, how to dramatize or not to dramatize it, how to provide it with agency and rationality, and so forth. For many authors, it seems that what was at stake was which adjectives to apply to the plot. There was no lack of them. Among the noteworthy ones, along with cruel,

${ }^{31}$ Speaking about 9/11, not the Gunpowder Plot, John Frow develops the idea in "The Uses of Terror and the Limits of Cultural Studies," Symploke 11, nos. 1-2 (2003): $69-76$.

32 William Barlow, Sermon Preached at Paules Crosse, the Tenth Day of Nouember Being the Next Sunday after the Discouerie of This Late Horrible Treason (London, 16o6), C2v.

33 John Rhodes, A Briefe Summe of the Treason Intended against the King and State, When They Should Haue Been Assembled in Parliament. Nouember. 5. I605 (London, 1606), A2v. 
inhumane, brutish, and devilish, one may note a frequent use of barbarous, furious, abominable, horrid, horrible, and terrible - words that by and large reappeared in Milton's work. Finding the right adjectives, attributing a certain moral, emotional, and psychological character to the plot and its plotters, the mythographers divided the world into the admirable, the acceptable, the unacceptable, and the intolerable.

But more to the point, the mythographers of the Powder Treason were concerned to "emplot it," in Paul Ricoeur's sense. The plotters themselves were concerned to provide a story line. The confessions of Fawkes and Winter, featured in the official accounts of the plot, loom large in the mythography, and the memoirs of Tesimond and Gerard, though not known to English readers in the seventeenth century, provide an interesting amplification of the impulses, wholly honorable by their own lights, that caused men like Fawkes, Winter, and Catesby to try to blow up the state. The questions treated by way of direct and indirect narration include the following: To what extent may the plotters, and the English Catholics they claimed to represent, be allowed to have suffered from grievances? To what extent were these grievances legitimate? Legitimate or not, how could they have inspired so violent and peremptory a course of action? What other motives might have urged the plotters forward? Was their behavior a consequence of official Catholic doctrine, or a perversion of that doctrine? Did the plotters act alone? Whether they acted alone or not, was their behavior sanctioned by other Catholics in England or abroad, or by officials of the Catholic Church or the governments of Catholic nations? Who knew about this plot in advance? What did they know, and when? Could anyone with advance knowledge have prevented it? How in any case was the plot actually foiled? How should the official English response to the plot be assessed?

James argued that the plotters had acted alone and perversely and yet in perfect keeping with the teachings of Catholicism. Barlow emphasized the radical, devilish singularity of the conspirators. Many writings lacked subtlety, to say the least. But a constant assumption of the mythographers, however carefully or abusively they expressed it, was that the plot was a symptom of something. For James, though the plot was not caused by Catholicism, it was a symptom of its teachings. For Barlow, though the plot, on a level of reason - of what we 
know about human nature and the political and religious situation of England now - was all but incomprehensible, it was a symptom of the nature of evil, a hyperbolic symptom. Thus it was an easy leap, as in Herring's Pietas Pontificia and Dekker's Double P.P. early on, to imagine that the plot was a symptom of both, a combination of Catholic doctrine and the persistence of evil, centered in the persons of Satan, the pope, or both. Some allegorical representations make this selfexpressiveness gruesomely palpable. In the first English translation of Pietas Pontificia, the conspiracy is personified as Treason, a "fearfull monster," and Treason itself is the child of Satan and the Whore (though Milton would not go along with it, many writers liked making a female out of the pope):

I sing a strange blacke monster, rude and fell, Late on that Whore which doth the world besot, In grosse thicke darknesse, utmost caves of hell, In curled coupling Lucifer begot

A fearfull monster, all our world to quell. ${ }^{34}$

Vicars's adaptation of the poem, Mischeefes Mysterie, changes Lucifer to Pluto and makes this act of self-expression through procreation more graphic:

Great Pluto, Prince of darknes Tartars King,

Became enamour'd of Romes Strumpet faire,

His lustfull pleasure then to passe to bring ...

... they enoy'd infernall copulation:

Whose hideous act did from her wombe express,

A monstrous birth exceeding admiration. ${ }^{35}$

Over the top, no doubt, but anticipating the birth of Death out of the coupling of Satan and Sin in Paradise Lost, these allegorizations assert that, whatever the real involvement of the Catholic Church, the conspiracy was an expression of its inherent nature. The Gunpowder Plot showed and in effect represented the alliance of the church with evil and of evil with the church.

${ }^{34}$ Francis Herring, Popish Pietie; or, The First Part of the Historie of That Horrible and Barbarous Conspiracie, Commonly Called the Powder Treason (London, 16o6), st. 3 .

${ }^{35}$ Francis Herring, Mischeefes Mysterie; or, Treasons Master-peece, the Powder-plot, trans. and adapted by John Vicars (London, 1617), B-Bv. 
Again, this was not the only way of analyzing or narrating the situation. Hawes attributed the plot wholly to self-destructive Machiavellianism on the part of the conspirators acting alone. Rhodes made some of the plotters into atheists. Hakewill failed to find any motive for the plot beside sheer malice. And note how easy it ought to have been to suggest, as Tesimond and Gerard and even Hakewill did, that the plot was a perversion of Catholic doctrine, an anomalous error. But the connection of the plot with Satan, hell, the pope, and ultimately the Antichrist, which made it neither anomalous nor, from its own perspective, an error, was the point of departure of the allegorizers and the hysterics — among them Dekker, Herring, Williams, Rhodes, Campion, Fletcher, and the young Milton. ${ }^{36}$

We come thus to the representation of terrorism as a symptom of the other. The Britons "to me do beare / No goodwill," complains the pope to Treason in Herring's Popish Pietie: "thy great Father too they spight, / And have much damage done to Peters chaire, / And Peters kingdome" (st. 5). "The Britons boast that they are safe within their sea walls and mock Roman thunder that is far off," complains a demon to Pluto in Campion's De Puluerea Coniuratione (43). Milton goes farther and clarifies the idea, making the strength of England in the face of evil and the Catholic Church a good deal more imposing than a simple "spight" or "boast" about being "safe." In Quintum Novembris returns the question of motives to the matter of the relation between the two sides in the quarrel, between Satan's church and the English people, and thus between evil and good. Flying above "Albion," in which recently the lands of the English and the Scots have been happily united, Satan, the "savage tyrant" ( ferus tyrannus), is alarmed. ${ }^{37}$ The sight of the white cliffs of "the land beloved by the sea-god," a land "blest with riches and festal peace," newly presided over by a pious and peace-loving king, is annoying. This, Satan says, is "the only distressful sight I have found in my wanderings over the world. This people alone rebels against me, spurning my yoke and too powerful for my art." Luther's Germany

36 Preachers, charged not to vilify the whole of the Catholic Church, were constrained in what they could write on the occasion of the Gunpowder Plot. See R. H. Robbins, review of John Donne's I622 Gunpowder Plot Sermon: A Parallel-Text Edition, ed. Jeanne Shami, Review of English Studies 5o (1999): 92-94.

37 Satan is given many names in the poem. 
and Calvin's Switzerland are both excluded from the picture, perhaps because they do not combine worship with sovereignty and prosperity, Germany being wartorn and divided and Switzerland being only precariously united. In any case, to the savage tyrant England is "the only distressful sight," populated by a people beloved and blessed and well governed, resisting the devil's hegemony. Worst of all, they are a people that worships "the sacred majesty of the one true God." But that needs to be changed. "They shall not long do this with impunity" or "without vengeance," Satan declares, spewing brimstone at the thought.

Not "with impunity," not "without vengeance" - the idea that terrorists seek a perverse justice, or that they couple a cry for justice with a cry for revenge, is not unusual among mythographers of terrorism, including those who contributed to the story of the Powder Treason. ${ }^{38}$ At the trial of the conspirators, Coke emphasized that point at length, and for the same reason that Milton would twenty years later: terrorism is an illegitimate appropriation of the tools of legitimacy. "Consider the place" at which the conspirators aimed their weaponry, Coke said, "the sacred Senate; the house of Parliament. And why there? For that say [the defendants], unjust Lawes had formerly beene there made against Catholiques: Therefore that was the fittest place of all others to revenge it, \& to do Justice in." "If any aske who should have executed this their Justice," Coke derisively continued, "it was Justice Fawkes, a man like enough to doe according to his name. And if any aske, 'by what Law they meant to proceed,' it was Gunpowder Law, fit for Justices of hell” (True and Perfect Relation, $\mathrm{Hv}-\mathrm{H}_{2}$ ). So it is with Milton, in the mouth of Satan: "with impunity," "without vengeance," according to the justice of hell, England was not supposed to be allowed to persevere.

Coming down to the level of human intervention in the plot against England, Satan has some more specific things to say about the differentness of the English people. He approaches the pope, who is depicted as an adulterer, a drunkard, an idolater heading his own empire of idolaters ("blind fools"), and also a subduer of kings, a regum domitor. This "barbaric people," the English, he tells the pope in a dream, threaten

38 I have been much helped on this topic by John Nicholls, "Gunpowder Plot and the Politics of Revenge" (unpublished paper, Lancaster Medieval and Renaissance Seminar Series, Lancaster University, February 20o6). 
the pope's dominion, openly and repeatedly, with "swelling spirits" and "shameless pride." The pope should avenge the loss of the Spanish Armada and - a more disturbing detail, perhaps an example of how the devil can twist the facts to suit his purposes, but perhaps, if Milton is telling it straight, simply a moral blind spot on his own part — "the bodies of so many saints hanged on the ignominious gallows during the recent reign" of Elizabeth. And if the pope should not arouse himself and take action - here again Satan twists facts, while also giving voice to English desires - the English will attack the pope instead, invade Italy, and occupy Rome itself, there destroying the Catholic altars and treading on the pope's neck.

So Satan is out to punish the British because they resist him, and his agent the pope is to set events in motion because, in the first place, they have harmed his dominions and, in the second place, if he does not, the British will destroy him. The militancy of the English provokes military retribution on the part of those against whom the English have been militant. The English hang priests, and if they have their way, they will destroy the government of Rome, wrecking their altars and killing their leader. But the response to which Satan exhorts the pope and his henchmen communicates the fact that the militancy of the English is potent and finely organized. "Do not attack [the English] with war and open conflict; that would be fruitless labor; rather make use of skillful fraud." And do so-this being an extremely important measure insofar as English thought on the subject would be concerned from the beginning-by striking at the English king and the parliament who represent them.

The dialectic of self and other, of cause and symptom, is consummated with this speech. It is precisely because of the strength of the British that the pope must lead an attack against them, and it is precisely because this strength is at once moral, political, and military that the Catholics are directed to use "skillful fraud." "Their great king is now summoning to council the dignitaries from the kingdom's remotest shores. ... these limb from limb you can blow to the sky." Attacking the king and his parliament will cause "the nation" to be "seized with panic and stunned by the catastrophe." Like Catesby and the others, Satan has allowed his imagination to get away from him and to move from the moment of the holocaust to an implausible scenario of for- 
eign intervention, local insurrection, and revolution: "Either the ruthless Gaul or the fell Iberian shall invade the land. Thus at length will the spirit of the Marian age return among them, and you [the pope] will rule again over the valiant English."

The attack on the governing elite and one of its most symbolically significant institutions, the brutal strategy of mass murder and mass destruction, the aim of inciting revolution, and the complex personal motives, ranging from resentment and vengefulness to fear and desperation, all speak to the systematicity of the uprising against the state. The perpetrators conspire to do the damage that the system of the English state invites, by way of England's adopted technology, in keeping with England's constitutional values and institutional infrastructure, and in response to what is taken to be England's own military ambitions. The conspirators' goal even agrees with the underlying apocalyptic fantasies of the Christian cause, which James himself, something of an expert on the matter, articulated in his first public comments on the plot. James compared the perverted intentions of the conspirators with God's intention soon enough "to punish the world the second time by Fire, to the generall destruction and not purgation thereof." That was another sign of their impiety and iniquity, the conspirators' arrogating to themselves a power that was only God's, but it was also a sign of affinities and continuities that were terrible to think about. ${ }^{39}$ Though one could say that this was one system, of governance and violence, of worship and schism, by adopting the logic of symptomology, writers like Milton can deny the systematicity of the problem even while acknowledging it. They can argue that Protestantism and Catholicism are engaged not in a struggle for the soul of European Christianity but in what today is called a "clash of civilizations." 40 Two incompatible, irreconcilable forces of "civiliza-

${ }^{39}$ His Maiesties Speach, B1v. James had published a work on the Apocalypse at the age of twenty-two: Ane Fruitfull Meditatioun Contening ane Plane and Facill Expositioun of ye 7.8.9 and Io Versis of the 20 Chap. of the Reuelatioun in Forme of ane Sermone. Set Doun be ye Maist Christiane King and Synceir Professour, and Cheif Defender of the Treuth, Iames the 6 King of Scottis (Edinburgh, 1588).

40 What quickly became the classic statement of this view is Samuel P. Huntington, The Clash of Civilizations and the Remaking of World Order (New York: Touchstone, 1997). 
tion" are vying for hegemony. Each to the other is "barbarous." In Milton's poem, indeed, as in many other contributions to the mythography, the accusations that may be brought against the conspirators and the forces of Catholicism that they represent are appropriated by the conspirators themselves in their accusations against the forces of English Protestantism. The unheard-of violence, the never-before-attempted elimination of a government by way of a weapon of mass destruction, was itself an outcome, in keeping with this dialectic, of the invincibility of the English. The violence speaks precisely because no violence, against $u$, perpetrated by them, can ever really work. Terrorism is a symptom of the other.

Even one of the priests involved with the conspirators, in his secret memoirs, exemplified this logic. "The Catholics in England," writes Tesimond, all but adopting the point of view of a clash of civilizations that Milton's Satan would adopt, "had arrived at the nadir of their miseries. There was no more hope for them. . . . Adrift on such a sea of miseries, what else could have been in the mind of those afflicted and every way discomfited Catholics if not the expectation that every day some new burden would be added: a further increment to the weight under which they already groaned." Though most Catholics were content with patience, he goes on, a minority "kindled within them a just desire, as it seemed to them, of retribution. They burned to liberate themselves and their friends from this cruel servitude and oppression. But at least they found a remedy for these evils which was no less lacking in pity and humanity than the very authors of such evil. Led by anger and desperation, they decided to open a way to new and better hopes by the utter destruction of their adversaries" $\left(5^{2}-53\right)$.

\section{Mythography Lost}

In Paradise Lost Satan is again discovered "compassing the earth" in flight, making his rounds "in meditated fraud and malice, bent / On man's destruction" $\left(9.59,55^{-56)}\right.$. His motives have already been touched on but are worth looking at more closely. Because he cannot win against God, Satan attempts to defeat the new domain of the Creator. He wishes to express his resentment, to exact revenge, to destroy, "to waste His whole creation," or perhaps rather to incite a revolution, and therefore either to 


\section{possess}

All as our own, and drive, as we were driven, The puny inhabitants, or if not drive, Seduce them to our party.

$$
(2.365-68)
$$

The multiplicity of possibilities entertained by Satan's party is a symptom not only of uncertainty but also of the desperate nihilism to which Satan has paradoxically pinned his hopes, and of the complexity of motives and aims that Milton had long since associated with terrorist aggression. The plan, says Satan's spokesman, "would surpass / Common revenge": it would

$$
\text { interrupt [God's] joy }
$$

In our Confusion, and our joy upraise

In his disturbance. $(2.370-73)$

At that point, in synod of the Fallen Angels, it is almost as if Satan were inspired to take pleasure in an episode of vandalism. "I abroad," he assures his crew, "Through all the Coasts of dark destruction seek / Deliverance for us all" $(2.463-65)$. Desires for empire and liberation, for "power over" and "freedom from," are mixed up in Satan's thoughts. They are combined in an ideology of resistance at any cost, resistance for its own sake, even resistance precisely because resistance is futile. It hardly matters whether he can triumph, Satan at one point says to himself. "For onely in destroying I find ease / To my relentless thoughts" $(9.129-30)$.

Satan's motives are dark and deep. For in the epic the Adversary is endowed not just with enmity and ambition but with a psychology. Satan is lashing out at his own pain, driven "to wreck [avenge] on innocent frail man his loss / Of that first Battel, and his flight to Hell" $(4.12-13)$. Satan is desperate.

\section{Now conscience wakes despair}

That slumberd, wakes the bitter memorie

Of what he was, what is, and what must be

Worse; of worse deeds worse suffering must ensue.

$$
(4.23-26)
$$

If, in terms of target and goal, Satan has some reason on his side - his target, after all, is something of a sitting duck, and his goal of revolution and empire is something that in the short term he actually attains - his 
psychology is at once deep, plausible, explicable, pathetic, and mad. "Be then [God's] love accurst," says Satan, madly reasoning with himself,

since love or hate,

To me alike, it deals eternal woe.

Nay curs'd be thou; since against his thy will

Chose freely what it now so justly rues.

Me miserable! which way shall I fly

Infinite wrauth, and infinite despaire?

$$
(4.69-74)
$$

Where In Quintum Novembris elides the agency of a terrorist plot, and therefore also the psychology of the terrorists, Paradise Lost dramatizes agency, making Satan not just the contriver of the conspiracy but its perpetrator, and so assigns to Satan a psychology, in fact the same psychology that writers like Tesimond were eager to assign to the perpetrators of the Gunpowder Plot.

Differences between the early and late poems are highly significant, however. For example, the gunpowder that during the Gunpowder Plot was mustered against England's ruling elite is in Paradise Lost mustered against God and Christ and the good angels. First introduced on the field of battle in heaven disguised in hollow tubes, as if a kind of "fraud," it is soon openly deployed by one army arrayed against the other. So the first use of gunpowder in the history of the Creation has nothing to do with terrorism. But consider then the weaponry mustered to further the terrorist-like plot against Adam and Eve and the Lord's "new world." No weapons are used at all. At the beginning of human history, the violence - and there is violence aplenty, the earth undergoing tremors, the sun slipping off its rotation, animals rising against one another, and humanity itself suddenly face to face with death - is an effect of betrayal, rather than betrayal itself. All that is necessary for the terrorist to accomplish his goals is seduction and deceit, aided by the enticements of a poisonous apple; the Creation itself will do the work of violence.

Earth trembl'd from her entrails, as again

In pangs, and Nature gave a second groan,

Skie lowr'd, and muttering Thunder, som [sic] sad drops

Wept at compleating of the mortal Sin

Original. (9.1000-1004) 
Thus the work of violence from one poem to the other has been complicated. In In Quintum Novembris the violence is retributive, tactical, and conscriptive in that order, moving from Satan to the pope to the conspirators. From the retribution, the murders, the panic, and the confusion will then come military intervention from abroad, on which occasion England will be reconverted to Catholicism. In Paradise Lost, by contrast, the violence is retributive, tactical, and conscriptive all at once. The conscription - that is, the seduction of Adam and Eve to the side of sin - is the violence, is the tactic, is the retribution. Temporizing and prevaricating at times, Satan is uncertain what kind of violence he is wreaking on the Creation, and he does not know, or refuses to know, that his own violence is part of God's providence. Satan claims that he wants to "seduce" a people to a false "party" not only to conscript more followers and thereby extend his dominion but also to destroy it:

that their God

May prove their foe, and with repenting hand

Abolish his own works.

He knows that what he is doing is potentially apocalyptic, but he does not or refuses to know that he is setting up the conditions for the Apocalypse and a final redemption. One destruction will lay the groundwork for another.

So there are differences. Clearly it will not do to reduce the main plot of Paradise Lost to a reiteration of the Powder Treason, any more than it will do to think of Paradise Lost as a completion of the project begun with In Quintum Novembris. But the affinities are obvious, and so are, on the one hand, the place of Paradise Lost in Milton's thought on the Gunpowder Plot and, on the other, the place of both in the mythography of terror that grew in response to the discovery of the plot. Early on, for Milton and any number of English Protestants in the seventeenth century, the thwarting of the Gunpowder Plot had clarified an old theological point, whose greatest exponent was Saint Augustine: that evil is oppositional but unequal; that evil is oppositional precisely because of the superior power of good. Evil is a symptom of the other. And it is a symptom in history. Though the shock and outrage were real in the early days after the plot, surely the verbal response to the plot betrays as well a certain pleasure, a joy in the confirmation 
of deeply held prejudices, fears, and otherwise uncertain expectations. The other-Catholicism, the pope, the Jesuits, the loose cannonry of fanatics, however one wants to depict it-is precisely what we need it to be. It is a murderous, ruthless, and unscrupulous Adversary plotting our destruction. Meanwhile, on the other side of the clash of civilizations, we are really what we have to be. We are the chosen, the saved. The Adversary cannot win, and we are the ones whom he cannot defeat. We not only have survived a false attempt at general destruction but are destined to survive the real general destruction when it comes. For this we ask thanksgiving, and for this the Fifth of November has become a national day of thanksgiving.

By the time Milton wrote Paradise Lost, however, between ${ }_{165} 8$ and 1665, the Gunpowder Plot was something of a dead letter in England. Only three works on the plot seem to have been published during those years, one of them the sermon by the excluded bishop Brownrig, the other two brief and unoriginal works of popular history. ${ }^{41}$ Cressy assures us that the Gunpowder anniversary, marked by sermons during the day and by bonfires at night, was celebrated throughout the period and that, "as always," it "provided a polysemous occasion which could be re-politicized for current purposes" (173). But not until about 1674, the year of Milton's death and a time when fears of a Catholic succession were newly exacerbated, would intense literary interest be aroused in it again.

Milton thus wrote Paradise Lost in a historical context where interest in the plot was minimal. The plot by this time was merely legendary, a "polysemous" assembly of ideological and poetic motifs. And Milton thus wrote Paradise Lost with a very different literary as well as political agenda from the one he undertook in In Quintum Novembris. If Paradise Lost is a work of "delirium," it is not perfectly topical, and it is not a work of cozy moral certainty or patriotic fervor. Whatever allegorical resonances it may have, the impulses behind allegorization have been attenuated. It would not do to argue by way of narrative that evil in the world, in history, was categorically identical with the terrorism of the Gunpowder traitors. That would ultimately undermine the proj-

41 Thomas Spencer, Englands Warning-Peece; or, The History of the Gun-Powder Treason (London, 1658); Gent, True and Perfect Relation. 
ect of the epic, for it would mean arguing the one thing the epic cannot argue, namely, that humanity is innocent, that humanity bears the same relation to evil that the English government bore to Catesby and his sponsors. But even so, underlying structures in tune with Milton's earlier thoughts about the Gunpowder Plot remain, though in fragments: gunpowder here, conspiracy there, violence in a third place. Yet they are no less troubling. If the impulse toward destruction remains affiliated with the Adversary, it has become dangerously psychologized. It has become something that one can almost understand and sympathize with. Meanwhile, destruction itself has been taken out of the Adversary's hands. The terrorist only guilefully persuades an unknowing innocent to light the fuse and bite into the apple. Moreover, though the terrorist counts vengeance as one of his chief goals, the targets of his vengeance have done nothing to deserve it. They have not resisted Satan; they have not frustrated Satan's drive toward empire. Instead, as sheep to Satan's wolfishness $\left(4.18_{3}-85\right)$, they simply provide subjects who can be at once recruited and victimized. It is God whom Satan is trying to harm and punish, though of course God can be neither hurt nor punished, and Satan knows it. In other words, where in In Quintum Novembris the unbeatable foe is Albion, a nation and government, at once a military power and a fount of pious virtue, whose humbling would seem plausible and advantageous, even demanded from a popish point of view, in Paradise Lost the unbeatable foe is God, who cannot be humbled, much less intimidated or terrorized. In fact, the targets of Satan's main plot in Paradise Lost, Adam and Eve, are utter noncombatants, in no need of humbling. They are already humble. Thus, although the coherent allegorical model of In Quintum Novembris has been complicated and fragmented in Paradise Lost, one can say that in the epic Satan's plot is the more terrible of the two, the more terroristic in the most modern usage. ${ }^{42} \mathrm{He}$ has injured a vulnerable and innocent population to strike back at an invulnerable God, and the

42 This is Laqueur's main point in No End to War: "Until recently, terrorism was, by and large, discriminate, selecting its victims carefully-kings and queens, government ministers, generals, and other leading political figures and officials. It was, more often than not, 'propaganda by deed.' Contemporary terrorism has increasingly become indiscriminate in the choice of its victims. Its aim is no longer to conduct propaganda but to effect maximum destruction" (9). 
long-term result is not only destruction itself — the bringing of death into the world - but the terrorization of the populations that remain. "O miserable mankind," as Adam first says on seeing the prospect of humanity after Satan's victory;

to what Fall

Degraded, to what wretched state reserv'd!

Better end heer unborn.

$$
\left(11.5^{\mathrm{OO}}-5^{\mathrm{O} 3}\right)
$$

Paradise Lost preserves the idea that violence and terror are systematic. This, I would venture, is the fundamental problem of the existence of terrorism, though not of evil per se. Terrorism depends on the system it attacks, and it is a part of that system, a political statement to the system. The challenge to those on the side of the targets of terrorism is thus to understand precisely how, from a political point of view, the condition of the victims can explain the desperate violence of the terrorists; the challenge is to perceive how the political condition of the victims has caused the attack on them. The idea that terrorism is a symptom of the other, as the young Milton, among many others, allegorically developed it, is one answer to the dilemma, an answer that has the virtue of exculpating the victims entirely, of explaining the terror as a consequence, precisely, of the victims' political virtue. Obviously, there were many attempts to do the same in the aftermath of $9 / 11$. But more to the point: if terrorism is systemic, and demands a moral and imaginative response that takes account of its systematicity, evil may well be something different. Evil may well be the unsystemic violence of a lone gunman on a college campus. But neither In Quintum Novembris nor Paradise Lost is about that kind of evil. There is nothing accidental about evil in either case. In the early poem, evil is directly if perversely caused by the strength and virtue of the targets of violence; in the late poem, evil is directly if perversely caused by the innocence of its targets, who are undeserving of evil in themselves but then are seduced into becoming deserving of it. Either way, evil is terroristic, and, by the logic of a mythography, terrorism is a symptom of the other. 
Robert Appelbaum is senior lecturer in Renaissance studies at Lancaster University. He is author, most recently, of Aguecheek's Beef, Belch's Hiccup, and Other Gastronomic Interjections: Literature, Culture, and Food among the Early Moderns (2006). A Leverhulme fellow for $2007-8$, he is working on a new book, tentatively titled Terrorism before the Letter. 


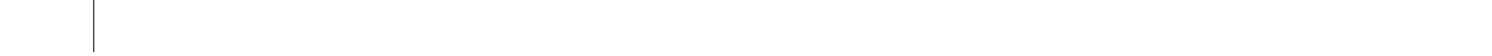

